Ethos (Jurnal Penelitian dan Pengabdian Masyarakat): 29-34

\title{
Peningkatan Pengetahuan hiv/AIDS dengan Memanfaatkan Aplikasi MOBILE ANDROID
}

\author{
${ }^{1}$ Sri Puji Utami, ${ }^{2}$ Herika Hayurani \\ ${ }^{1,2}$ Fakultas Teknologi Informasi Universitas YARSI, Jl. Letjen Suprapto, Cempaka Putih, Jakarta 10510

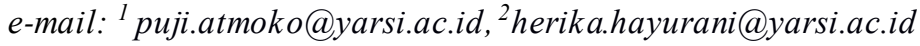

\begin{abstract}
Abstrak. Penyebaran virus HIV/AIDS semakin meningkat di Indonesia. Penyebaran terjadi terutama pada kelompok usia muda. Prevalensi HIV pada usia 15-49 tahun diproyeksikan meningkat. ODHA (Orang dengan HIV/AIDS) pada tingkat awal, belum dapat merasakan adanya virus HIV yang ada pada dirinya, sehingga tanpa adanya pengetahuan tentang hal tersebut penularan dapat terjadi. Potensi pemanfaatan teknologi mobile untuk kesehatan khususnya untukpen anggulangan penyebaran HIV/AIDS cukup tinggi. Masyarakat Indonesia termasuk kaum muda sudah terbiasa untuk tidak terlepas dari ponselnya, sehingga akan mudah mendapatkan informasi terkini terkait HIV/AIDS. Pada penelitian ini diujico bakan aplikasi mobile berbasis Android sebagai perangkat edukasi bagi kelompok usia muda tentang pencegahan dan penularan penyakit HIV/AIDS. Aplikasi Android in $i$ digunakan untuk memberikan penyuluhan HIV/AIDS kepada 143 mahasiswa di Jakarta. Hasil yang didapat dari penyuluhan ini adalah adanya peningkatan pengetahuan tentang HIV/AIDS dari mahasiswa sebesar $25,87 \%$ tentang cara penularan, 17,48\% tentang cara pencegahan dan 25,17\% tentang fakta HIV/AIDS setelah dilakukan penyuluhan menggunakan aplikasi mobile berbasis Android.
\end{abstract}

Kata kunci: HIV/AIDS, mobile, android, edukasi

\section{Pendahuluan}

Penyebaran virus HIV/AIDS semakin meningkat di Indonesia. Taksirannya 371.800 pada tahun 2010 menjadi 541.700 pada tahun 2014 (DepKes, 2009). Penyebaran terjadi terutama pada kelompok usia muda, yang seharusnya dapat berperan sebagai penerus bangsa. Prevalensi HIV pada usia 15-49 tahun diproyeksikan meningkat dari 0,22\% tahun 2008 menjadi 0,37\% tahun 2014 (DepKes, 2009). ODHA (Orang dengan HIV/AIDS) pada tingkat awal, belum dapat merasakan adanya virus HIV yang ada pada dirinya, sehingga tanpa adanya pengetahuan tentang hal tersebut penularan dapat terjadi. Misalnya antara seorang muda yang berganti-ganti pasangan.

Strategi dan Rencana Aksi Nasional (SRAN) 2010-2014 diharapkan dapat memandu program-program yang efektif mencegah dan mengurangi penularan HIV antara lain : penelitian yang menunjang pengembangan upaya baru penanggulangan HIV dan AIDS (KPAN, 2009). Upaya baru penanggulangan HIV/AIDS ini dapat ditindaklanjuti dengan pemanfaatan TIK (Teknologi Informasi dan Komunikasi) yang saat ini terus berkembang, termasuk teknologi mobile. Pemanfaatan teknologi mobile saat ini lebih ke arah bisnis dan perbankan. Belum banyak pemanfaatan teknologi mobile dalam bidang kesehatan, terutama di Indonesia.

Potensi pemanfaatan teknologi mobile untuk kesehatan khususnya untuk penanggulangan penyebaran HIV/AIDS cukup besar. Masyarakat Indonesia termasuk kaum muda sudah terbiasa untuk tidak terlepas dari ponselnya, sehingga akan mudah mendapatkan informasi terkini terkait HIV/AIDS. Penyuluhan HIV/AIDS menggunakan aplikasi mobile merupakan upaya baru yang berbeda dari model penyuluhan pada 
umumnya. Di sini peserta lebih aktif untuk membaca dan mempelajari konten yang terkait.

\section{Tinjauan Pustaka}

\section{A. HIV/AIDS}

Acquired Immune Deficiency Syndrome (AIDS) disebabkan oleh Human Immunodeficiency Virus (HIV). HIV adalah virus sitopatik diklasifikasikan dalam keluarga Retriviridae, sub keluarga Lentivirinae, marga Lentivirus. Acquired Immunodeficiency Syndrome atau Acquired Immune Deficiency Syndrome (AIDS) adalah sekumpulan gejala dan infeksi yang timbul karena rusaknya sistem kekebalan tubuh manusia akibat infeksi virus HIV. Virus dapat berada dalam tubuh seseorang tanpa menimbulkan gejala sakit yang berarti, selama bertahun - tahun bahkan 10 - 11 tahun (Nasronudin, 2007).

Pada saat ini penderita HIV di Indonesia semakin meningkat terutama di perkotaan maupun di daerah yang pertumbuhan ekonominya cukup pesat. Menurut laporan data yang bersumber dari Ditjen PP \& PL Kemenkes RI tentang Statistik Kasus HIV/AIDS di Indonesia pada tahun 2012, jumlah terbanyak pada kasus AIDS menurut golongan umur terdapat pada remaja berusia 20 - 29 tahun yang berjumlah 13.761 jiwa (Ditjen PPM \& PL Depkes RI, 2010). Dengan banyaknya jumlah kasus AIDS pada kalangan remaja di Indonesia, membuat banyak pihak berpikir dan tergerak untuk segera menurunkan bahkan menghentikan jumlah kasus AIDS di Indonesia. Sangat disayangkan jika orang-orang yang memiliki potensi tersebut tertular HIV secara tidak mereka sadari. Begitu banyak remaja yang akan kehilangan masa depan jika kasus ini tidak segera dihentikan.

\section{B. Mobile Health}

Perkembangan TIK saat ini, memungkinkan hampir tiap orang yang tinggal di perkotaan terutama memiliki ponsel. Melalui ponsel, sosialisasi atau informasi tentang HIV/AIDS memiliki probabilitas cukup tinggi untuk dibaca dan dicermati oleh si penerima informasi. Mobile health sudah berkembang di negara-negara maju dan negara-negara berkembang, seperti India dan Ethiopia (Vital Wave Consulting Report, 2009).

Ada beberapa sistem operasi mobile seperti IOS, Symbian, RIM (Blackberry), Windows Phone, dan Android. Hadirnya Android sebagai salah satu sistem operasi dari smartphone, telah memberikan nuansa tersendiri dari teknologi mobile saat ini. Ada kelebihan dan kekurangan untuk implementasinya sebagai mobile health. Kelebihannya smartphone saat ini digandrungi kaum muda. Aplikasinya dapat diambil secara gratis di market Android. Dengan demikian cakupan terhadap sasaran kaum muda akan lebih banyak.

\section{Android}

Android adalah sistem operasi Mobile Phone berbasiskan Linux. Android bersifat open source yang source codenya diberikan secara gratis bagi para pengembang untuk menciptakan aplikasi mereka agar dapat berjalan di Android. Pada mulanya, Android adalah salah satu produk dari Android Inc., kemudian Google mengakuisisi Android Inc., dan semua kekayaan intelektual milik Android Inc. diperoleh Google Inc. 
yang kemudian mengembangkan kembali sistem Android. Keunggulan Android diantaranya (Tarkoma, 2009) :

1. Keterbukaan; Android menyediakan akses ke fungsi dasar perangkat mobile menggunakan standar panggilan ke API (Application Programming Interface).

2. Integrasi data kontak; informasi dari Internet dapat digabungkan ke dalam telepon, seperti informasi kontak, atau data pada lokasi geografis untuk mendapatkan informasi terkini.

3. Kesamaan aplikasi; untuk Android ada perbedaan antara telepon utama aplikasi dan perangkat lunak lain, sehingga dapat mengubah program untuk memutar nomor, atau screen saver.

4. Cepat dan mudah; perkembangan dalam SDK memiliki semua yang dibutuhkan untuk membuat dan menjalankan aplikasi Android, termasuk instrumen simulator, dan alat debugging yang canggih.

\section{Metode}

Metode yang digunakan untuk meningkatkan pengetahuan responden terkait HIV/AIDS adalah dengan mengadakan kegiatan penyuluhan menggunakan aplikasi mobile berbasis android. Sebelum dan sesudah penyuluhan para responden diberikan kuesioner. Responden diberikan waktu yang cukup untuk dapat memahami hal-hal terkait HIV/AIDS dari aplikasi mobile. Dari hasil yang diperoleh didapatkan tingkat pemahaman dari responden sebelum dan sesudah berinteraksi dengan aplikasi mobile. Beberapa tahapan yang dilakukan sebagai berikut :

1. Menyiapkan perangkat yang akan digunakan seperti smartphone atau ponsel android.

2. Memasang aplikasi android ke dalam perangkat yang akan digunakan untuk melakukan edukasi. Aplikasi yang digunakan ini sudah dibuat sebelumnya dari hasil penelitian (Utami, 2012). Tampilan aplikasi dapat dilihat pada Gambar 1.

3. Membuat kuesioner untuk mengukur hasil dari kegiatan edukasi. Kuesioner ini mengukur pengetahuan tentang cara penularan HIV/AIDS, pengetahuan tentang cara pencegahan dari tertular HIV/AIDS, pengetahuan tentang fakta HIV/AIDS.

4. Menyebarkan kuesioner sebelum penyuluhan.

5. Melaksanakan penyuluhan.

6. Menyebarkan kuesioner setelah penyuluhan.

7. Menganalisis kuesioner.
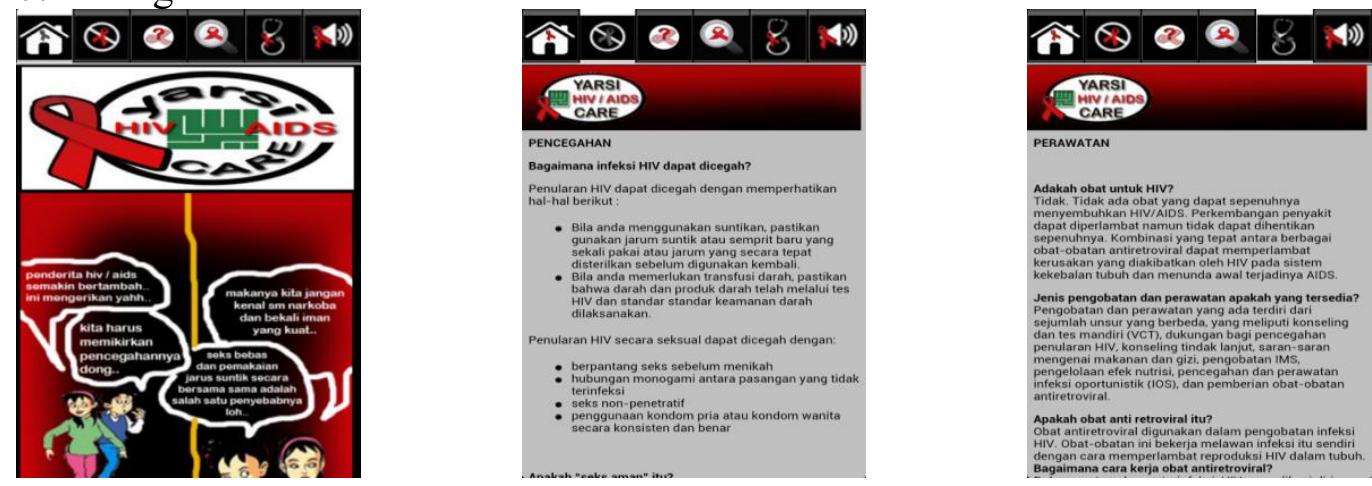

Gambar 1. Beberapa Tampilan Aplikasi Mobile YHAC Versi 1.0. 


\section{Hasil dan Pembahasan}

Kegiatan penyuluhan menggunakan aplikasi mobile berbasis android digunakan untuk memberi edukasi tentang HIV/AIDS kepada mahasiswa/mahasiswi FTI Universitas YARSI. Hasil analisa didapat berdasarkan pengolahan data terhadap isian kuesioner dari sampel yang diperoleh dengan cara non-random sampling quota yaitu dari seluruh jumlah populasi yang ada diambil sampel berdasarkan kuota yang ditentukan. Responden penelitian adalah 143 mahasiswa yang terdiri dari 88 pria $(61,5 \%)$ dan 55 wanita $(38,5 \%)$, dengan rentang usia 17 - 25 tahun. Gambar 2 menunjukkan seorang responden yang sedang menggunakan aplikasi.

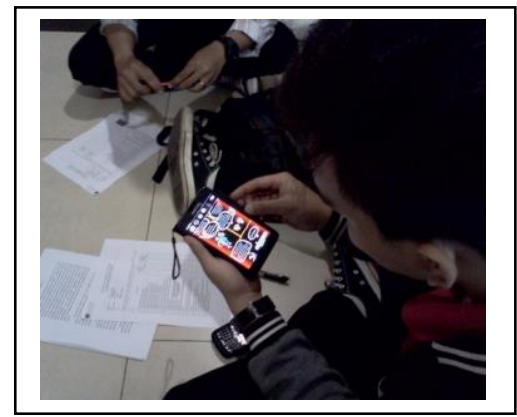

\section{Gambar 2. Mahasis wa me nggunakan aplikasi YHAC Versi 1.0.}

Sampel memiliki karakteristik, yaitu 31 orang $(21,68 \%)$ sudah pernah tahu tentang HIV/AIDS melalui media massa, 7 orang $(4,90 \%)$ melalui penyuluhan, 97 orang $(67,83 \%)$ melalui media massa dan penyuluhan, dan 8 orang $(5,59 \%)$ belum pernah tahu melalui media massa dan belum mendapat penyuluhan sebelumnya.

Kuesioner tentang pengetahuan HIV/AIDS dilaksanakan dua kali, yaitu pada saat sebelum menggunakan aplikasi mobile kemudian pada saat setelah menggunakan aplikasi mobile. Pertanyaan yang diajukan sebelum dan setelah menggunakan aplikasi mobile dinilai untuk dilihat peningkatan pengetahuannya. Kuesioner untuk mengukur pengetahuan tentang cara penularan terdiri dari 8 soal. Bila responden menjawab benar sebanyak $7-8$ pertanyaan maka dikategorikan baik. Bila responden menjawab benar sebanyak $5-6$ pertanyaan maka dikategorikan sedang. Bila responden menjawab benar sebanyak $3-4$ pertanyaan maka dikategorikan cukup. Bila responden menjawab benar sebanyak $1-2$ pertanyaan maka dikategorikan kurang. Demikian pula pada kuesioner untuk mengukur pengetahuan tentang cara pencegahan dari tertular HIV/AIDS dan pengetahuan tentang fakta HIV/AIDS.

Berdasarkan Gambar 3, hasil pengolahan kuesioner terkait pengetahuan HIV/AIDS tentang cara penularannya sebelum menggunakan aplikasi mobile didapatkan hasil baik $52 \%$, sedang $38 \%$, cukup $10 \%$, kurang $0 \%$. Setelah menggunakan aplikasi mobile didapatkan hasil baik $65 \%$, sedang $29 \%$, cukup $6 \%$, kurang $0 \%$. 


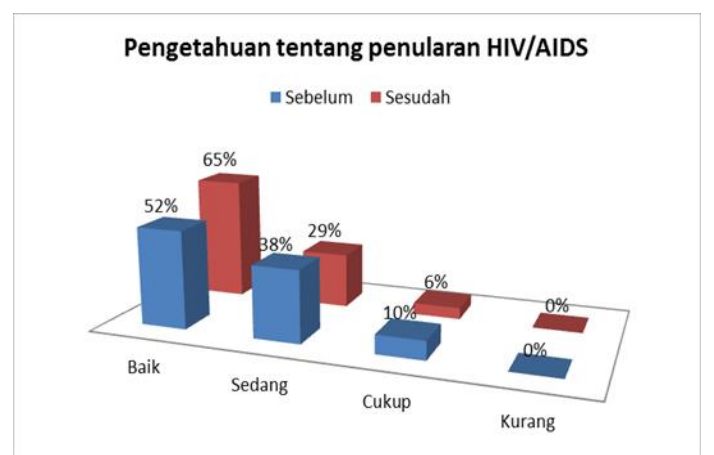

\section{Gambar 3. Diagram Has il Kuesioner Pengetahuan tentang Penularan HIV/AIDS Sebelum dan Sete lah Menggunakan Aplikasi Mobile}

Terjadi peningkatan pengetahuan dari cukup ke sedang sebesar 4,2\%, dari cukup ke baik sebesar $2,8 \%$, dan dari sedang ke baik sebesar $18,88 \%$. Total peningkatan pengetahuan sebesar $25,87 \%$.

Berdasarkan Gambar 4, hasil pengolahan kuesioner terkait pengetahuan HIV/AIDS tentang cara pencegahannya sebelum menggunakan aplikasi mobile didapatkan hasil baik 64\%, sedang 33\%, cukup 3\%, kurang 0\%. Setelah menggunakan aplikasi mobile didapatkan hasil baik $66 \%$, sedang $28 \%$, cukup $6 \%$, kurang $0 \%$.

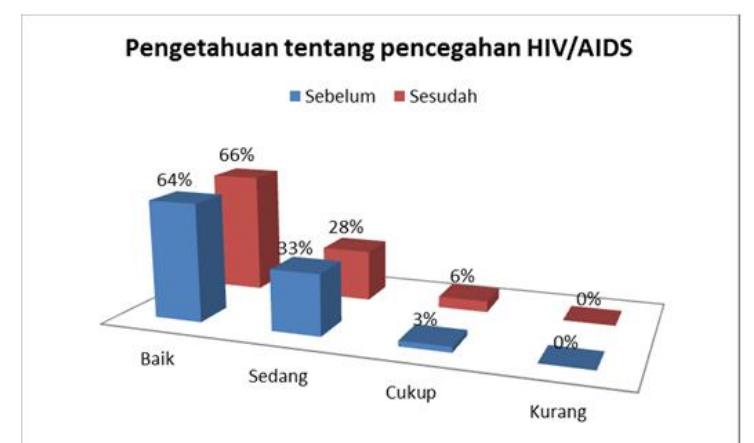

Gambar 4. Diagram Hasil Kuesioner Pengetahuan tentang Pencegahan Sebelum dan Se telah Menggunakan Aplikasi Mobile

HIV/AIDS

Terjadi peningkatan pengetahuan dari cukup ke sedang sebesar 1,4\%, dari cukup ke baik sebesar 1,4\%, dan dari sedang ke baik sebesar 14,69\%. Total peningkatan pengetahuan sebesar $17,48 \%$.

Berdasarkan Gambar 5, hasil pengolahan kuesioner terkait pengetahuan HIV/AIDS tentang fakta penyakit tersebut sebelum menggunakan aplikasi mobile didapatkan hasil baik $4 \%$, sedang 56\%, cukup 34\%, kurang 6\%. Setelah menggunakan aplikasi mobile didapatkan hasil baik $8 \%$, sedang 60\%, cukup 27\%, kurang5\%.

Pengetahuan tentang fakta HIV/AIDS

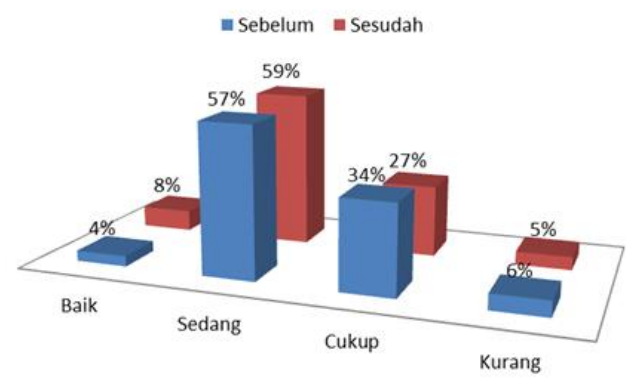




\section{Gambar 5. Diagram Hasil Kuesioner Pengetahuan tentang Fakta HIVIAIDS Sebelum dan Setelah Menggunakan Aplikasi Mobile}

Terjadi peningkatan pengetahuan dari kurang ke sedang sebesar 3,5\%, dari cukup ke sedang sebesar 15,38\%, dari cukup ke baik sebesar $2,1 \%$, dan dari sedang ke baik sebesar $4,2 \%$. Total peningkatan pengetahuan sebesar $25,17 \%$.

\subsection{Analisa Hasil Kuesioner}

Pengetahuan tentang HIV/AIDS sudah pernah dimiliki oleh 94,41\% responden, yaitu $21,68 \%$ melalui media massa, 4,9\% melalui penyuluhan ataupun $67,83 \%$ melalui media massa dan penyuluhan sebelumnya. Hasil kuesioner sebelum penyuluhan menggunakan aplikasi mobile tentang cara penularan HIV/AIDS mendapatkan hasil baik $52 \%$, hasil baik $64 \%$ tentang cara pencegahan dan hasil baik $4 \%$ tentang fakta HIV/AIDS. Hasil ini memperlihatkan bahwa pengetahuan tentang HIV/AIDS masih perlu untuk diulang dan diperbaharui.

Hasil kuesioner setelah penyuluhan menggunakan aplikasi mobile memperlihatkan adanya peningkatan. Terjadi peningkatan pengetahuan sebesar 25,87\% tentang cara penularan, $17,48 \%$ tentang cara pencegahan dan $25,17 \%$ tentang fakta HIV/AIDS. Hasil ini memperlihatkan bahwa penyuluhan menggunakan aplikasi mobile dapat meningkatkan pengetahuan.

\section{Kesimpulan}

1. Penyuluhan HIV/AIDS menggunakan aplikasi mobile dapat meningkatkan pengetahuan respondennya tentang HIV/AIDS.

2. Pengetahuan tentang penularan serta pencegahan HIV/AIDS perlu dilakukan secara terus menerus untuk menekan jumlah penularannya.

\section{Daftar Pustaka}

DepKes (2009). Pemodelan Matematik Epidemi HIV di Indonesia, 2008-2014.

Ditjen PPM \& PL Depkes RI (2010). Statistik Kasus HIV/AIDS di Indonesia, Laporan Triwulan IV tahun 2010. Ditjen PPM \& PL Depkes RI, Jakarta-Indonesia.

KPAN (2009). Strategi dan Rencana Aksi Nasional Penanggulangan HIV dan AIDS 2010-2014. Jakarta.

Nasronudin (2007). HIV \& AIDS Pendekatan Biologi Molekuler, Klinis, dan Sosial.

Tarkoma, Sasu (2009). Mobile Middleware : Architecture, Pattern and Practice, Interscience Wiley.

Utami, S.P. dan Hayurani, H. (2012). "Rancang Bangun Aplikasi YARSI HIV/AIDS Care Berbasis Mobile Tahun Pertama", Laporan Penelitian Hibah Unggulan Perguruan Tinggi, FTI Universitas YARSI.

Vital Wave Consulting Report (2009). Sizing the Business Potential of mHealth in the Global South, Copyright 2009, Vodafone Group Foundation, Rockefeller Foundation, United Nation Foundation. 